\title{
ЕВРАЗИЙСКИЙ ЭКОНОМИЧЕСКИЙ СОЮЗ: РОЛЬ РОССИИ И ПЕРСПЕКТИВЫ РАЗВИТИЯ
}

\section{EURASIAN ECONOMIC UNION: ROLE OF RUSSIA AND PROSPECTS FOR DEVELOPMENT}

\section{B. Kusainov}

Summary. The article discusses the main features and role of Russia in the EAEU aspect. The author presents a critical look at the role of Russia in cooperation with the EAEU member countries, identifies the main problematic issues, as well as the positive aspects of integration. The aim of the study was to highlight and analyze the main interactions and the role of Russia in the framework of the EAEU. The study described the main difficulties in the relations between the participating countries, and the impact of the nature of integration on economic cooperation. The EAEU can be perceived as a structure that has a core and a common strategy for economic development, so today we have to talk about deepening cooperation, which gradually goes beyond the scope of a purely economic field. Moreover, the expansion strategy of the EAEU should correspond to the scenario of forming an "own center of forces", which implies the creation of a consolidated entity of geoeconomic and geopolitical relations, the introduction of an effective model of regional international cooperation. The EAEU, documented, is an economic, technocratic project that provides some advantages to its members, in particular in facilitating cross-border trade and facilitating labor migration, but also creates economic risks by raising external tariffs and potentially orienting the economy away from global markets. Until now, the EAEU has not had much economic success, although access to the Russian labor market has been an important motivator and, ultimately, a positive result for postSoviet economies.

Keywords: EAEU, integration, Russia, economy, cooperation, harmonization.

\author{
Кусаинов Бауржан Оразалович \\ Павлодарский государственный университет имени \\ C. Торайгырова \\ A-D888@bk.ru
}

Аннотация. В рамках статьи рассматриваются основные особенности и роль России в аспекте ЕАЭС. Автор представляет критический взгляд на роль России в сотрудничестве со странами-членами ЕАЭС, выделены основные проблемные вопросы, а также положительные стороны интеграции. Целью исследования явилось освещение и анализ основных взаимодействий и роли России в рамках ЕАЭС. В ходе исследования описаны основные сложности взаимоотношений стран-участниц, и влияния характера интеграции на экономическое сотрудничество. ЕАЭС можно воспринимать как структуру, имеющую ядро и общую стратегию экономического развития, поэтому сегодня приходится говорить о углублении сотрудничества, которое постепенно выходит за рамки чисто экономической области. При этом стратегия экспансии ЕАЭС должна соответствовать сценарию формирования «собственного центра сил», предполагающего создание консолидированного субъекта геоэкономических и геополитических отношений, внедрение эффективной модели регионального международного сотрудничества. ЕАЭС, документально, - это экономический, технократический проект, который дает некоторые преимущества его членам, в частности в облегчении трансграничной торговли и облегчении трудовой миграции, но также создает экономические риски, повышая внешние тарифы и потенциально ориентируя экономику на отдаление от глобальных рынков. До сих пор ЕАЭС не имел большого экономического успеха, хотя доступ к российскому рынку труда был важным мотиватором и, в конечном счете, позитивным результатом для постсоветских экономик.

Ключевые слова: ЕАЭС, интеграция, Россия, экономика, сотрудничество, гармонизация.

Россия остается основным торговым и политическим центром ЕАЭС. Дисбаланс также проявляется в экономическом контексте: большинство макроэкономических показателей не коррелируют между странами-членами. Если судить по величине валового внутреннего продукта, рассчитанной по паритету покупательной способности (ВВП на ППС), то у России данный показатель в 2017 году составил 4007,831 млрд.долл. США. Вторая по величине страна ЕАЭС - Казахстан - достигла 477,593 млрд.долл. США. Иногда интеграционные компромиссы нелегко достичь, но основной системой координат была и остается логика 
общего стратегического выбора - продолжения движения к процессам глубокой экономической интеграции

С начала реализации проекта евразийской интеграции была решена значительная часть задач: эксперты стран Евразийской экономической комиссии провели большой объем работы и достигнут значительный прогресс: действует таможенный союз и введен единый таможенный тариф; создается общий рынок труда и услуг, присутствует единый рынок лекарств и медицинской продукции, принимают новые технические регламенты, создается Суд ЕАЭС, Евразийский банк развития, Евразийский фонд стабилизации и развития, в 2025 году планируется создать единый финансовый регулятор.

Современные проблемы, которые вызваны пандемией, могут также сыграть негативную роль в темпах роста экономических показателей в ЕАЭС. Возникнут проблемы развития МСБ, так как в первую очередь пострадает этот бизнес. В этом аспекте могут пострадать и интеграционные связи России со странами-членами ЕАЭС в области экспорта и импорта товаров, может снизиться товарооборот. Помимо этого, в странах ЕАЭС после окончания пандемии, помимо негативных последствий, возможно увеличение сплоченности и как следствие в будущем, будет формироваться более сплоченная интеграционная политика.

С учетом задач по углублению экономической интеграции и необходимости увеличения конкурентоспособности экономик стран наиболее перспективным признается сценарий «собственный центр силы», реализация которого даст возможность государствам-членам увеличить свою долю в мировой экономике, диверсифицировать экспорт (при одновременном увеличении объема экспорта продукции ТЭК (топливно-энергетического комплекса)), понизить зависимость от импорта из третьих стран, продукции ТЭК, создать долгосрочную основу для устойчивого экономического роста и увеличения качества жизни населения [3].

Однако, несмотря на прогнозы, евразийская интеграция сталкивается с трудностями, в том числе с некоторой несогласованностью моделей экономического развития, отсутствием различных институтов и отсутствием консенсуса внутри стран-членов, а также с приоритетностью собственных модернизационных проектов, не всегда совпадающими с приоритетами и рядом других факторов. Основным риском на данном этапе является «уход» от интеграции и превращение Союза в конструкцию, которая сочетает высокий уровень формализации правил и процедур принятия решений с низкими ожиданиями стейкхолдеров (заинтересованных сторон) от соблюдения этих норм. Об этом, в частности, говорит сложность и протяженность процесса согласования позиций в области стратегических нормативных документов ЕАЭС, принятых в последние годы (ТК ЕАЭС, соглашение по формированию общего рынка лекарственных средств и др.). В связи с этим необходимо принять меры по приданию значимого содержания евразийской повестке дня, включая осуществление совместных программ и проектов, развитие трансграничного промышленно-технологического сотрудничества, формирование региональных производственно-сбытовых цепочек, сочетание национальных преимуществ в процессах производства технологически сложной продукции и т.д. [6]

Перед странами стоит непростая задача балансирования стратегических интересов всех стран-членов союза в условиях зачастую противоречивых тенденций мировой экономики: регионального протекционизма, интеграции ассоциаций в лице внешних партнеров, а также соблюдения курса либерализации торговли, который был провозглашен ВТО и по-прежнему актуален. Помимо этого, нельзя забывать и о геополитических факторах, влияние которых на экономическую составляющую международных отношений значительно повысилось. Таким образом, задача евразийской интеграции представлена не только эффективным экономическим развитием стран Союза и повышением их конкурентоспособности, но и успешной интеграцией евразийского блока в мировую торгово-экономическую архитектуру как конкурентный «центр силы» мировой экономики. Приоритеты развития ЕАЭС на период до 2025 года включают:

- повышение эффективности единого рынка ЕАЭС и реализацию его возможностей для бизнеса и потребителей;

- создание инновационной территории и поощрение технического прогресса;

- раскрытие интеграционных возможностей для людей, улучшение их благосостояния и качества жизни;

- развитие ЕАЭС, как одного из важнейших центров развития современного мира, открытый для беспроигрышного и равноправного сотрудничества с внешними партнерами и построения новых форматов взаимодействия.

Международное сотрудничество в рамках евразийской интеграции - один из главных стратегических приоритетов России. Как показывает глобальный опыт, участие в региональной интеграции является наиболее эффективным способом реализации собственных экономических интересов. Успешная реализация развития ЕАЭС соответствует стратегическим и геоэкономическим интересам России, оказывая содействие более эффективного осуществления ее национальных приоритетов. Так, согласно п. 51 Концепции внешней политики Российской Федерации, утвержденной Указом Президента Российской Федерации от 30 ноября 2016 г. 
№ 640, Российская Федерация рассматривает в качестве ключевой задачи углубление и расширение интеграции в рамках ЕАЭС с Республикой Армения, Республикой Беларусь, Республикой Казахстан и Кыргызской Республикой в целях завершения формирования в рамках общего рынка товаров, услуг, капитала и рабочей силы, включая устранение барьеров, препятствующих интеграции в Евразийский экономический союз, ограничения и отмена изъятий в экономическом сотрудничестве при одновременном повышении активного использования механизмов для проектной деятельности, является одной из целей национального проекта развития международного сотрудничества и экспорта.

Приоритетное направление международной интеграции и экономического сотрудничества для России представлено:

- включением в орбиту евразийской интеграции новых направлений, в том числе в социально-гуманитарном плане;

- развитием последовательной политики ЕАЭС в ключевых секторах экономики (они представлены транспортом, энергетикой, промышленностью и сельским хозяйством), постепенным согласованием сферы финансовых рынков с выходом на единый финансовый рынок и наднациональный финансовый регулятор;

- установлением взаимовыгодных отношений ЕАЭС с третьими странами;

- взаимодействием ЕАЭС с другими форматами интеграционных объединений - с СНГ, китайской инициативой «Один пояс-один путь», инфраструктурными программами развития Северного морского пути, развитием механизмов сотрудничества между ЕАЭС и ЕС.

Это требует от России интегрированной и системы действий в отношении собственных экономических интересов в ЕАЭС, согласования подходов к стратегическому планированию на национальном уровне с целями евразийской интеграции, переноса опыта управления проектами и реализации международных стандартов. В качестве приоритета в рамках ЕАЭС в 2018-2019 гг. РФ определила некоторые приоритетные инициативы в рамках евразийской интеграции [5].

Президент РФ В. Путин в своем обращении к главам государств ЕАЭС по случаю начала председательства дал понять, что эта задача заключается в необходимости «внутреннего пожертвования для развития ЕАЭС, обеспечения полного и безоговорочного соблюдения всеми государствами-членами норм Союза и принятых обязательств, даже если это предполагает корректировку национального законодательства». Повестка России в рамках председательства в ЕАЭС стала одной из самых широких и инновационных, включающих в себя не только уже ставшие традиционными направления интеграции (как продолжение курса по определению условий торговли с третьими странами, индустриального и агропромышленного сотрудничества), но и новые направления, в том числе социально-гуманитарное развитие, сотрудничество в сфере образования и научных исследований, сотрудничество в области туризма, спорта, освоения космоса и т.д.

В частности, приоритетное внимание в повестке дня российского председательства было уделено активному формированию единого цифрового пространства ЕАЭС. В этой сфере особенно заметен эффект синхронизации действий стран Союза: в частности, по итогам заседания Евразийского межправительственного совета 28 ноября 2018 года был подписан указ «О разработке концепции применения специальных режимов в рамках реализации цифровой повестки дня Союза». Важный лейтмотив российского председательства в ЕАЭС в 2018 году стал представлен прогнозированием и определением стратегических приоритетов будущего развития евразийской интеграции, что отразилось в декларации о дальнейшем развитии интеграционных процессов в рамках ЕАЭС. Важным направлением для России и ЕАЭС является расширение международного сотрудничества Союза и подключение к орбите совместной интеграции других постсоветских стран. Стоит отметить, что Республикой Молдова был получен статус страны-наблюдателя при ЕАЭС, и планируется продолжить совершенствование института стран-наблюдателей при ЕАЭС, в том числе с учетом сочетания двух интеграционных форматов ЕАЭС и СНГ [2].

Однако, для России участие в ЕАЭС должно формировать некоторые вопросы, на которые необходимо ответить, в частности, как максимизировать влияние евразийской интеграции на национальную экономику, учитывая национальные приоритеты социально-экономического развития; как увеличить уровень восприятия и значимости евразийской интеграции для граждан. Каждая страна-участница ЕАЭС должна ответить на эти вопросы, и от этого во многом зависит эффективность интеграционной ассоциации в целом. В то же время важно не забывать, что ЕАЭС является органической частью мировой экономики и конкурентного мирового рынка. Нынешняя ситуация, безусловно, влияет на экономические показатели всех государств «евразийской пятерки». Поиск точек сближения, общего знаменателя для всех стран ЕАЭС при ответе на внешние вызовы, составление перечня социально совместных интеграционных проектов, включение «Евразийского измерения» в национальные документы стратегического планирования и более глубокое понимание экономических и политических последствий интеграции для стран союза, в том числе для 
России, являются важными целями, от решения которых зависит будущее ЕАЭС.

Евразийский экономический союз (ЕАЭС), созданный в 2015 году Россией, Казахстаном, Кыргызстаном, Беларусью и Арменией, претендует на то, чтобы стать первой успешной постсоветской инициативой по преодолению торговых барьеров и продвижению интеграции в раздробленном, недостаточно развитом регионе. Сторонники утверждают, что это мог бы быть механизм для диалога с Европейским союзом (ЕС) и другими международными партнерами. Критики изображают дестабилизирующий проект, который усиливает доминирование России в регионе и ограничивает отношения других ее членов с Западом. ЕС рассматривает этот проект как вызов суверенному выбору в своем восточном соседстве. Позиции укрепились после выхода Армении в 2013 году из соглашения об ассоциации с ЕС, включая глубокую и всеобъемлющую зону свободной торговли, и событиями в Украине [4].

Более тесная экономическая интеграция в рамках ЕАЭС должна сделать менее вероятными конфликты между ее членами (например, между Россией и Казахстаном). Облегчение трансграничной торговли и передвижения может снизить напряженность в Центральной Азии. Тем не менее, если Россия использует ЕАЭС для политического доминирования в регионе и в качестве платформы для конфронтации с Западом, то другие члены организации, скорее всего, будут рассматривать его как угрозу своей независимости. Конкурирующие экономические партнерства - будь то с ЕС или Китаем тогда выглядели бы более привлекательными, потенциально создавая напряженность в отношениях между членами ЕАЭС и Москвой.
Неопределенная роль и будущее ЕАЭС, а также противостояние с Россией из-за Крыма и Восточной Украины затрудняют ЕС разработку последовательной политики в отношении нее. Некоторые брюссельские чиновники и государства-члены выступают против любых переговоров, опасаясь, что они узаконят политику России по отношению к ее соседям и разорвут двусторонние отношения между ЕС и Арменией, Казахстаном, Кыргызстаном и Беларусью - все они за последние годы испытали новый импульс. Другие утверждают, что взаимодействие ЕС с ЕАЭС является возможным каналом для прорыва в отношениях с Россией или, по крайней мере, что оно может помочь построить мосты или даже снять давление со стран Восточного соседства и Центральной Азии, некоторые из которых жаловались на то, что оказались в ловушке между Москвой и Брюсселем.

Политическое взаимодействие между двумя блоками в настоящее время вряд ли реально, особенно до тех пор, пока не будут выполнены такие условия, как выполнение Минских соглашений по украинскому конфликту. В то время как Москва неоднократно выражала заинтересованность в формализации отношений, многие в ЕС опасаются, что такой шаг приведет к, по существу, пустому процессу с видимостью нормальных отношений, но минимальными существенными выгодами.

Однако при условии полного осознания вышеуказанных рисков технические переговоры на низком уровне между должностными лицами ЕС и ЕАЭС могли бы помочь в разработке будущих стратегий и предложить некоторые прагматичные краткосрочные выгоды, по крайней мере с точки зрения определения существа будущих дискуссий.

\section{ЛИТЕРАТУРА}

1. Договор о Евразийском экономическом союзе (г. Астана, 29 мая 2014 года) (с изменением от 15.03 .2018 г.) // https://online.zakon.kz/Document/?doc_ $\mathrm{id}=31565247$

2. Декларация о дальнейшем развитии интеграционных процессов в рамках Евразийского экономического союза (утв. распоряжением Высшего Евразийского экономического совета от 6 декабря 2018 г. № 9).

3. Евразийская экономическая интеграция: перспективы развития и стратегические задачи шля России [Текст]: докл. к XX Апр. междунар. науч. конф. по проблемам развития экономики и общества, Москва, 9-12 апр. 2019 г. / Т. В. Бордачев, К. О. Вишневский, М. К. Глазатова и др.: отв. ред. Т. А. Мешкова: Нан. исслед. ун-т «Высшая школа экономики». - М.: Изд. дом Высшей школы экономики, 2019. — 123 с.

4. Основные направления деятельности Правительства Российской Федерации на период до 2024 года (утв. Правительством Российской Федерации 29 сентября 2018 г.).

5. Основные направления экономического развития Евразийского экономического союза (утв. Решением Высшего Евразийского экономического совета от 16 октября 2015 г. № 28).

6. The Eurasian Economic Union: Power, Politics and Trade // https://www.crisisgroup.org/europe-central-asia/central-asia/eurasian-economic-union-power-politicsand-trade 